\title{
O jornalismo feminino de Clarice Lispector: em busca do inesperado e da desordem
}

\author{
APARECIDA MARIA NUNES \\ Universidade Federal de Alfenas
}

\begin{abstract}
This study revisits research begun in the 1980s to recover Clarice Lispector's work published in the Brazilian press. Lispector used the pages of various periodicals to publish poems, short stories, and small narratives that, subjected to later revision, would become landmarks in her literary production. Such is the case of the recipe for killing coakroaches that she published as a columnist for "Entre Mulheres" in the weekly Comício in 1952. Working under the name Tereza Quadros, Lispector reveals in "Entre Mulheres" a feminist agenda that interrogates the condition of women in the 1950s and makes of the section a platform for the dissemination of ideas brought from post-war Europe.
\end{abstract}

Keywords: Literature and journalism, Comício, beauty manuals, Tereza Quadros, Veronica Dengel

Dezembro de 1945. É a data da dedicatória de Elisa Lispector para a irmã Clarice, ao presenteá-la com o livro Beleza e personalidade por Veronica Dengel: o livro azul da mulher. Talvez esse presente pudesse ser apenas mais um em meio aos que a escritora recebeu. No entanto, a "afetuosa lembrança," como registrou Elisa, reveste-se de importância por sinalizar alguns aspectos que devem ser levados em conta quando estudamos o percurso de Clarice na imprensa brasileira, notadamente na produção de páginas femininas.

Não foi aleatória a escolha do livro com que Elisa presenteou Clarice. A obra de Veronica Dengel tornou-se best-seller no Brasil daqueles anos, por apresentar de forma hábil e didática "os segredos" da beleza feminina calcados em padrões 
de uma sociedade ainda patriarcal. Além do mais, quando Clarice Lispector produziu suas páginas femininas para os jornais Comício, Correio da Manhã e Diário da Noite, ${ }^{1}$ as lições de Dengel lá estavam. No entanto, e esta é a proposta deste estudo, Lispector, sem se denominar "feminista," adotou postura de resistência às imagens femininas de uma sociedade proselitista. Em sua "desordem midiática," inspirada nas leituras que fez de Simone de Beauvoir, Katherine Mansfield, Virginia Woolf e Rosamond Lehmann, entre outras, a colunista apresentou a sua leitora carioca um modelo de mulher contrário ao divulgado pelos manuais de beleza e comportamento femininos, como os publicados por Dengel, em que a mulher é medida pela sociedade por sua eficiência doméstica, conjugal e física. Para tanto, a fim de defendermos tal proposta, vamos nos valer apenas das páginas femininas de Comício, que são emblemáticas e funcionam como protótipo no que se refere à produção clariciana de colunas dirigidas à leitora de jornal. O contexto de época, bem como algumas particularidades da vida da escritora, relacionadas a determinadas leituras, às influências, ao estilo de escrever ficção e textos jornalísticos, aos valores pessoais e à maneira como entendia a sociedade, constituem aspectos esses que subjazem na construção do perfil de mulher do jornalismo feminino que exerceu e por isso, aqui, também serão examinados.

Antes, porém, de avaliarmos as relações da obra de Veronica Dengel, citada no início deste estudo, com as páginas femininas de Clarice Lispector, é importante pontuar alguns fatos da biografia da autora de $A$ maçã no escuro (1964), para aferir certas influências na temática clariciana e na imagem da leitora que se inscreve nas colunas femininas sob seus cuidados.

Em 1945, ano em que foi presenteada com o livro de Dengel, a caçula dos Lispector desfrutava de considerável prestígio no panorama cultural do Brasil. Era já escritora consagrada de Perto do coração selvagem, lançado em 1943, pela editora A Noite, empresa pela qual trabalhou por aqueles anos como repórter, enquanto cursava a faculdade de Direito. Aliás, é bom esclarecer, Clarice publicou ficção e matéria jornalística nos principais órgãos de imprensa da cidade

\footnotetext{
${ }^{1}$ Clarice produziu três colunas femininas em jornais da cidade do Rio de Janeiro. No semanário Comício, utilizou o pseudônimo de Tereza Quadros para a página "Entre Mulheres" (1952); no Correio da Manhã, foi a Helen Palmer da coluna "Correio Feminino" (1959-1961); e no Diário da Noite escreveu como a ghost writer da atriz e manequim Ilka Soares na página "Só para Mulheres" (1960-1961). Ver Nunes (Clarice Lispector jornalista).
} 
do Rio de Janeiro, antes da edição de seu primeiro romance, frequentando com assiduidade as redações e despertando a atenção de veteranos colegas como Antônio Callado, Francisco de Assis Barbosa e Lúcio Cardoso, entre outros.

O casamento com o colega de classe Maury Gurgel Valente, realizado em 23 de janeiro de 1943, não a impediu de continuar trabalhando em A Noite, até a conclusão do curso de Direito, junto com o marido, em dezembro deste ano. Antes de colar grau, o casal partiu para Belém do Pará, onde Maury fora designado para trabalhar como vice-cônsul. Foi em Belém do Pará que Lispector acompanhou o lançamento de seu primeiro romance e as críticas. No final de julho de 1944, a então senhora Gurgel Valente iniciou viagem ao exterior, em decorrência do trabalho do marido diplomata, e um período de quase 16 anos longe do Brasil. Em Nápoles, com uma Europa em guerra, finalizou seu segundo romance, O lustre, iniciado no Rio de Janeiro, em março de 1943, e publicado pela Agir no final de 1946.

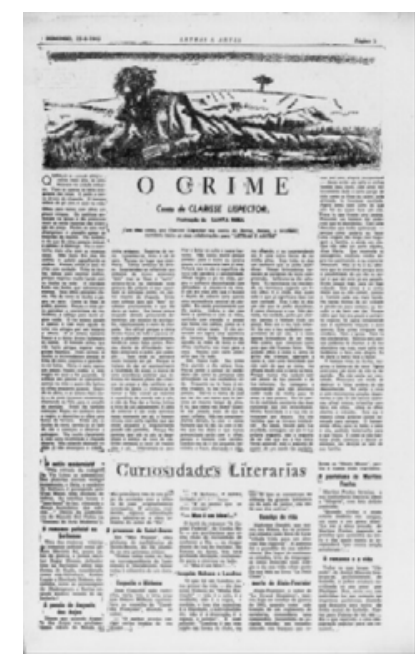

Figura 1: Fac-símile da página dominical do "Letras e Artes," de 1946, com a publicação do conto "O Crime." Importante observar o destaque da diagramação, com a ilustração de Santa

Rosa, e a advertência de que Lispector escrevia de Berna e iniciava sua colaboração no suplemento. Fonte: Fundação Biblioteca Nacional (Rio de Janeiro).

De Nápoles, Clarice e Maury, com rápida passagem pelo Brasil, mudaramse para Berna, na Suíça, em 1946. Apesar de a guerra ter terminado, Clarice 
enfrentou lá um período difícil de vida. Entretanto, foi em Berna que nasceu o primeiro filho, Pedro, e ela escreveu A cidade sitiada (1949), além de alguns contos que enviou para publicação no suplemento "Letras e Artes" do jornal $A$ Manhã, com ilustrações do conceituado artista Santa Rosa. ${ }^{2}$ Os contos "O crime," "O jantar" e "Noite na montanha" foram diagramados com destaque e com a observação que a autora os enviava de Berna.

De volta ao Rio de Janeiro, em 1949, mesmo que por pouco tempo, em decorrência da remoção de Maury Gurgel Valente para a Secretaria de Estado, na qual ocupou o cargo de estagiário, Clarice Lispector foi recebida como fenômeno literário. E o "Letras e Artes" a entrevistou no escritório da editora A Noite, onde, de acordo com a reportagem, Clarice verificava as provas do romance A cidade sitiada. A matéria deu enfoque especial à volta da ficcionista ao país, fez breve retrospecto de sua carreira, quando descoberta por Lúcio Cardoso, divulgou as impressões de Lispector sobre a Suíça e noticiou a publicação do novo romance. Pelo texto da reportagem, podemos notar que Clarice já demonstrava relutância em ser entrevistada, pois a matéria chegou a advertir o leitor que houve uma luta entre o repórter e a romancista: "Nós queríamos entrevistá-la, e ela, sequiosa de notícias brasileiras, tentava a todo custo entrevistar-nos." "3 A reportagem fez questão ainda de conferir se Lispector sonhava com a romancista britânica Rosamond Lehmann, como acontecia em quase todos os dias de 1943. Em resposta ao "Letras e Artes," ela confessou que esses sonhos a abandonaram. Lehmann, aliás, era escritora muito lida no círculo de Lúcio Cardoso, em que transitava Lispector.

A entrevista concedida ao "Letras e Artes" reforça informações importantes sobre a carreira inicial de Clarice Lispector e sinaliza que Rosamond Lehmann era mais que leitura privilegiada da jovem ficcionista. Podemos inferir que havia entre as duas escritoras - Lispector e Lehmann-forte identificação motivada provavelmente pelo fato de ambas estrearem na literatura aos 23 anos de idade. Lehmann, por outro lado, também era o tipo de mulher que se destacava pela

\footnotetext{
${ }^{2}$ Os contos farão parte dos livros Alguns contos e Laços de família.

${ }^{3}$ Clarice Lispector também atuou como entrevistadora na imprensa brasileira. Foi a responsável por duas séries de entrevistas nas Empresas Bloch: revistas Manchete e Fatos \& Fotos/Gente. A observação feita na entrevista ao "Letras e Artes" não foi meramente circunstancial. Clarice sempre relutou em conceder entrevistas. Preferia entrevistar.
} 
beleza, inteligência, talento e charme. Atributos que, como sabemos, eram igualmente conferidos a Lispector.

Lehmann, portanto, sempre foi uma inspiração e uma paixão para a jovem Clarice, principalmente, entre outros quesitos, pela linguagem da escritora britânica ser marcada pelo poder da descrição como recurso para desencadear o aparecimento de sensações e emoções, instaurando assim o tom poético. Prova disso foram os comentários que Clarice fez, quando se encontrava na Europa, em cartas às irmãs Elisa e Tânia (Minhas queridas). De Nápoles, em 21 de novembro de 1944, ela contou com entusiasmo que tinha comprado em Roma o livro Poussière, de Lehmann, a tradução francesa de Dusty Answer. E recomendou: "Você devia ler, é uma maravilha. É difícil encontrar no Rio, mas é capaz de algum de seus conhecidos e amigos possuí-lo" (62). Talvez, pelo título e características da obra inaugural Perto do coração selvagem (1943), que motivaram aproximações da linguagem clariciana com a de James Joyce, outras influências não ganharam a devida discussão nos meios acadêmicos. A não ser, posteriormente, os estudos em torno de comparações com Katherine Mansfield e Virginia Woolf. No entanto, é preciso esclarecer que, nos anos da década de 1940, as mulheres, conforme nos revela Gilda de Mello e Souza, "admiravam muito as representantes femininas." Gilda cita Mansfield e Woolf, mas reforça o nome de Lehmann, com a ressalva de ser "uma jovem escritora hoje esquecida."

A leitura atenta da página "Entre Mulheres" de Comício, por exemplo, mostrará que Clarice, enquanto Tereza Quadros, ${ }^{4}$ adotou postura reflexiva sobre mulher e feminilidade, e não somente uma reprodução do status quo, como em outras publicações da imprensa feminina dos anos 1950. De alguma maneira, a influência de Lehmann no texto de Lispector se fez sentir na construção dos modelos de mulher que perpassam esses escritos, como a mulher independente que constrói seu caminho. Contudo, as personagens femininas de Lehmann e Lispector demonstram pungente sensibilidade e se inclinam ao isolamento, em enredo muitas vezes marcado por atmosfera fluida. De março de 1951 até setembro de 1952, Clarice Lispector permaneceu no Rio de Janeiro e retornou à

\footnotetext{
${ }^{4}$ Comício grafava o nome "Tereza” com “z” em alguns momentos e, em outros, com "s.” Optamos
} pela grafia com "z." 
imprensa carioca, ao aceitar convite do amigo Rubem Braga para um trabalho diferente de tudo o que já tinha feito até então. ${ }^{5}$

\section{O Brasil pós-guerra que Clarice encontrou}

No Rio de Janeiro, Clarice observou as mudanças de valores e de comportamento que se instauraram com o fim da Segunda Guerra Mundial. A indústria do consumo ganhou fôlego. A mulher, ao mesmo tempo em que usufruía dos fios sintéticos, alimentos industrializados e aparelhos eletrodomésticos, começava a participar, ainda que timidamente, do mercado de trabalho, assumindo novas funções. A imprensa brasileira também passou por transformações técnicas, gráficas e editoriais. A tradição francesa, do periodismo mais opinativo, cedeu espaço ao modelo norte-americano, que privilegiava o factual.

O amigo Rubem Braga, com o fim da guerra, viajou diversas vezes para a Europa. Em Paris, no final de 1949, foi correspondente do Correio da Manhã. Depois de algum tempo por lá, quis voltar ao Brasil, mas relutou, enquanto Getúlio Vargas estivesse no poder. Foram idas e vindas, de Paris ao Rio de Janeiro, até que, em 1952, decidiu lançar um tabloide, Comício, juntamente com Rafael Corrêa de Oliveira e Joel Silveira. O semanário, então, reuniu em torno de si quase todos os homens de imprensa antigetulistas da época. Curiosamente, o jornal foi lançado no momento em que Clarice Lispector visitava o país e a equipe de Comício abrigava uma desconhecida Tereza Quadros. Dessa maneira, Lispector retornou ao jornalismo, para assinar página feminina sob pseudônimo. Clarice Lispector foi então Tereza Quadros e a redatora de "Entre Mulheres."

O semanário Comício teve sede na Cinelândia, mais precisamente na rua Álvaro Alvim. Impresso na gráfica do Última Hora de Samuel Wainer, o tabloide de vida efêmera circulou de 15 de maio a 17 de outubro de 1952, totalizando

\footnotetext{
${ }^{5}$ Lispector já reunia considerável experiência jornalística na cidade do Rio de Janeiro, sobretudo nos anos iniciais da década de 1940, antes de se casar com Maury Gurgel Valente em 1943. A jovem Clarice, paralelamente à publicação de sua ficção em alguns periódicos conceituados, como Pan , Dom Casmurro, Diário do Povo e Folha de Minas, atuou na Agência Nacional, a partir de 1940, como repórter e redatora. Na Vamos Ler!, revista semanal da empresa A Noite, Clarice, entre 1940 e 1941, além de ter publicado contos seus, traduziu texto, fez entrevista e reportagem. Enquanto aluna da Faculdade Nacional de Direito, foi colaboradora em 1941 da revista acadêmica A Época. Em 2 de março de 1942, Clarice ganhou seu primeiro registro profissional em carteira: é repórter do jornal A Noite. Ver Nunes (Clarice Lispector jornalista e Clarice na cabeceira); Abreu; Buitoni e Sullerot.
} 
apenas 23 edições. $\mathrm{O}$ jornal tentou sobreviver com anunciantes, mas as dívidas de impressão acumulavam-se mês a mês, não restando alternativa a não ser fechar o jornal de "espírito moleque," como escreveu Rubem Braga a Clarice Lispector, em 23 de maio de 1953.

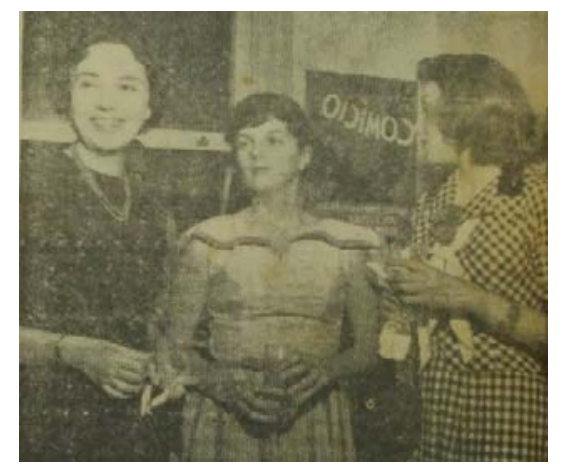

Figura 2: Clarice (à direita, em vestido xadrez), no coquetel de lançamento de Comício, juntamente com as esposas de Fernando Sabino (Helena Valadares Sabino, no centro) e Dante

Viggisni. Fonte: Comício, no 2, edição de 22 de maio de 1952, p. 20. Arquivo pessoal de Aparecida Maria Nunes.

A página feminina de Comício foi ideia de Rubem Braga, responsável também pela escolha do nome Tereza Quadros. Talvez por estar salvaguardada pelo pseudônimo, Clarice Lispector aceitou produzir "Entre Mulheres." Mas, mesmo com todos esses cuidados em ocultar o trabalho de Lispector em Comício, nem bem a escritora partiu para Washington, onde ficaria por mais oito anos, a verdadeira identidade de Tereza Quadros foi revelada pelo próprio jornal. Uma matéria na edição de número 13 do tabloide, em 8 de agosto de 1952, página 26, intitulada "Comício perde seu melhor redator, mas reage brilhantemente," demonstrou que a seção de Tereza Quadros gozava de prestígio e atestou ser uma das melhores páginas do semanário. O texto informou ainda que Tereza Quadros parte "para o estrangeiro em começos de setembro, e a arrumação das malas não lhe dá mais tempo. E agora, que ela se despede, podemos apresenta-la com o seu nome verdadeiro: é a escritora Clarice Lispector, senhora do consul Mauri Gurgel Valente." Muito querida pelo seu círculo de amizades, Clarice foi substituída pela jornalista Elsie Lessa, mulher do escritor Orígenes Lessa. A página "Entre 
Mulheres," em virtude disso, primeiramente deixou de ser assinada e depois, a partir da $20^{a}$ edição, em 26 de setembro de 1952, não foi mais veiculada.

A partir da página feminina que produziu exatamente como Tereza Quadros, podemos encontrar informações que nos ajudam a estudar a produção da jornalista e da ficcionista Clarice Lispector, pois a coluna "Entre Mulheres" é composta por temas, discussões, crônicas e embriões de textos que consagrariam a escritora em obras posteriores. Tereza Quadros, habilidosa, escreveu sobre assuntos comuns à mentalidade do público feminino da época. Afinal, no Brasil da década de 1950, havia um modelo de mulher ideal a ser perseguido por todas aquelas que almejavam uma vida feliz e um destino de realização. O Estado, a Igreja, a Medicina e a sociedade brasileira instituíram o casamento de padrão tradicional como o ideal dominante. E esse ideal, na verdade, desenhou o paradigma que nos auxiliará a examinar as colunas femininas escritas por Clarice Lispector, tendo em vista que as que produziu para o Correio da Manhã e Diário da Noite na virada para a década de 1960 já estavam sob a tônica dos processos de modernização da sociedade e dos movimentos de emancipação feminina, com a presença crescente da mulher no mercado de trabalho. Mas, em 1952, o Brasil vivia a herança de uma cultura europeia religiosa e tradicional, na qual a mulher era vista ainda como reprodutora, esposa e dona de casa. Por isso, a página feminina de Comício, bem como o trabalho de Lispector como Tereza Quadros, não poderiam subverter as normas de mercado e dos interesses da leitora daquele tempo. A página sugerida por Rubem Braga deveria estar voltada para questões do feminino, não tendo, portanto, caráter panfletário ou de lutas em favor dos direitos da mulher.

Antes, porém, de expor como Clarice Lispector introduziu a desordem na página "Entre Mulheres," destacamos que os veículos de comunicação instigavam (se ainda não o fazem) determinadas condutas de suas leitoras em consonância com a moral vigente e com as estruturas sociais, impingindo um modelo de mulher. Era comum a difusão de manuais de comportamento e beleza. Ou seja, o corpo, os gestos, os estilos, o vestuário, os gostos e os desejos femininos passavam por uma regulamentação propagada pela mídia, inclusive. A imagem da mulher ideal era modelada na conquista de destinos igualmente previsíveis e tidos como os que garantiriam a felicidade tão almejada. Um desses manuais era justamente o Beleza e personalidade por Veronica Dengel com o 
qual Elisa presenteou a irmã caçula, em dezembro de 1945 e que sempre esteve na biblioteca particular de Clarice.

A edição norte-americana do livro de Elisa (Personality unlimited: The beauty blue book) foi publicado em 1943, e logo se tornou sucesso em vários países. No Brasil, a obra foi traduzida e adaptada por Elza Marzullo, cronista de beleza da revista $O$ Cruzeiro, que foi a responsável pela edição e distribuição dessa obra de Denzel, com ilustrações originais, "destinada ao aperfeiçoamento da beleza feminina, com todos os requisitos para uma vida mais alegre e sadia," conforme propaganda veiculada em $O$ Cruzeiro. Por essa ocasião, a mídia já incorporava a beleza como valor social, tendo como público-alvo a dona de casa de classe média. Para tanto, passou a problematizar a questão do tempo a ser administrado pela mulher, que, além de se dividir entre as tarefas de cunho doméstico e a educação de filhos, deveria agora cuidar da aparência pessoal. Sessões como a de Elza Marzullo e a de Tereza Quadros já incutiam na leitora a síndrome da "eterna juventude," não somente como signo de beleza feminina, mas, sobretudo, como predicado para a conquista e manutenção do homem amado, conforme o modelo de perfeição delineado pelo imaginário da época e sustentado pelos manuais de instrução femininos.
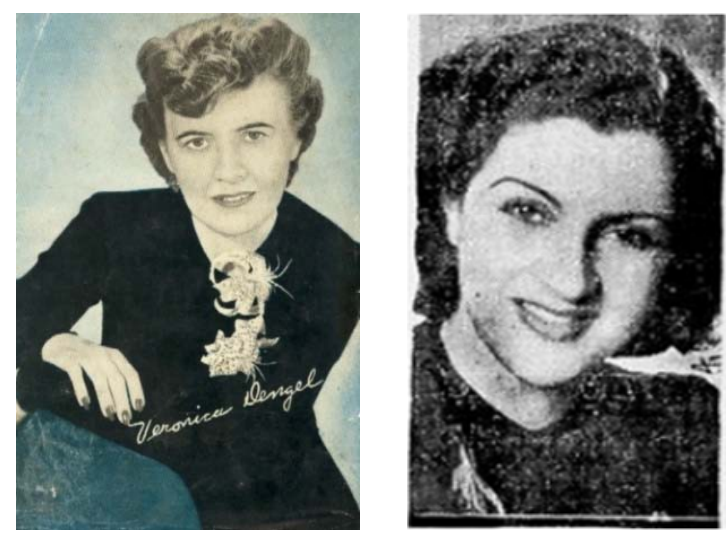

Figura 3: Fotos de Dengel, à esquerda, e de Elza Marzullo, à direita. Fontes: sítio historiadaestetica.com.br e Diário da Noite, respectivamente.

Nas páginas femininas que escreveu, Lispector adotou o princípio de beleza proposto por Dengel, que ensinava que a mulher deveria se analisar para 
conhecer seus pontos fortes e valorizá-los. Além do mais, conforme o conceito de beleza propagado pela escritora norte-americana, Clarice também insistiu junto às leitoras brasileiras que a mulher bela é aquela que cultiva pele macia, cabelos sedosos e olhos brilhantes, ou seja, para ser admirável era preciso ser saudável e asseada. Tais predicativos não foram elencados por acaso. A vida prática da mulher atualizada começava a ser adotada como padrão nos anos 1950 mediante avanços tecnológicos da indústria. Ao lado de novos aparelhos eletrodomésticos (refrigerador, enceradeira, liquidificador, batedeira) e de utilidades do lar (esponja de limpeza Bom Bril, sabão em pó), surgiram os lançamentos de produtos de higiene e beleza (xampu, pasta dentifrícia, cotonetes, desodorantes). A mídia, então, instigava a mulher ao consumo, relegando receitas caseiras e um modo de vida simples.

Para que a beleza pudesse ser adquirida, tanto Dengel como Lispector ensinavam que uma mulher atraente é a que sabe cuidar do próprio corpo, e cuidar do corpo implicava adotar alimentação saudável e manter o peso em consonância com a silhueta de beleza feminina sustentada pela mídia. Exemplo desse discurso se encontra na página "Entre Mulheres," em que Tereza Quadros associou beleza ao tempo que a mulher dispensa a si, ao argumentar que, para os homens, o tempo é dinheiro, "mas para a mulher o tempo é também beleza. Os dois minutos gastos nesta massagem, com creme nutritivo de sua preferência, vão render muitas horas de uma pele mais bonita e mais resistente" (Comício, 15 de agosto de 1952, 18). A exemplo de Veronica Dengel, a colunista Tereza Quadros informou às suas leitoras que os cuidados com a saúde são necessários para a afirmação de uma imagem de beleza feminina e que elas deveriam se esforçar para combater os maus hábitos. Além do mais, é importante mencionar, o culto ao corpo feminino dos anos 1950, na busca da "feminilidade," acabou por exaltar os cuidados com a cintura. A moda, responsável por essa mentalidade, esteve ancorada no New Look criado por Christian Dior, que, logo após os anos de guerra, em 1947, rebelou-se contra a austeridade e incitou as mulheres a erguerem a autoestima. Com ressonâncias da década anterior, os anos 1950 não somente consagraram as saias godê e os sutiãs de bojo, como também promoveram a feminilidade por meio de silhuetas bem delineadas, no formato de ampulhetas, para destacar os quadris, atraindo, assim, a atenção de homens. 


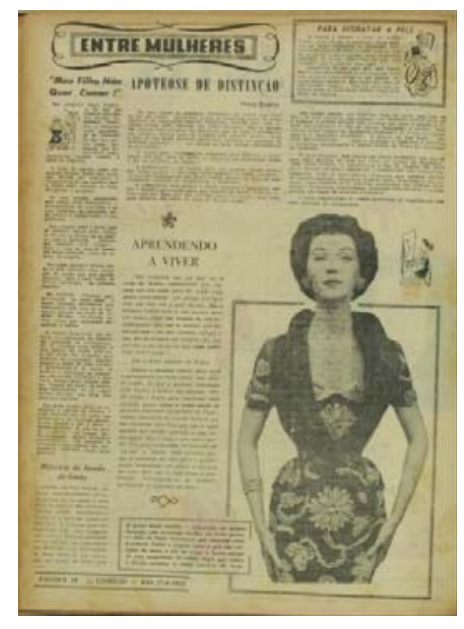

Figura 4: Vestuário sugerido por Tereza Quadros, com destaque para o requinte do tecido e o modelo com a cintura bem marcada, permitindo a silhueta em forma de ampulheta. Edição de 27 de junho de 1952, de Comício. Arquivo pessoal de Aparecida Maria Nunes.

Feminilidade, diante da proposta, foi sinônimo de cintura extremamente demarcada. Por isso, exercícios de extensão foram sugeridos pelas duas conselheiras femininas no programa de beleza da mulher, como forma de conservar a saúde e de valorizar o corpo. Clarice Lispector, como vemos, não destoou do paradigma Felicidade-Saúde-Beleza em suas páginas femininas. A leitora de "Entre Mulheres," neste contexto, se assemelhava a de outras colunas, ao consumir um modelo de feminilidade burguês. Essa mulher veiculada pela imprensa era a casada (ou que pretendia casar-se), com filhos (ou que os desejava), que cuidava da casa e se cuidava para o marido (ou namorado). Tudo muito igual a outras páginas femininas e ao establishment.

\section{Padrão de feminilidade}

Quando falamos em manuais de beleza ou receituários femininos, não podemos deixar de nos reportar aos antigos almanaques de farmácia, responsáveis por divulgar medicamentos e formas de cuidar da saúde, mas também por estabelecer novos padrões de comportamento, mediante uma mentalidade de civilização, que vigorava no Brasil desde o final do século XIX. Distribuídos gratuitamente em farmácias, os almanaques se tornaram populares em todo o território nacional. 
As tiragens alcançavam as cifras de milhões de exemplares e, com base nas ideias positivistas que sustentaram a elite, não foi difícil difundir no imaginário contemporâneo uma imagem discursiva do corpo e de seus estereótipos.

Nos anos 1950 e início dos 1960, disputando espaço com os programas televisivos, surgiram também os manuais de instrução femininos e os jornais passaram a dar atenção às colunas dedicadas à leitora. Por essa ocasião, alguns guias de comportamento se destacaram, como Biblioteca do lar, Dicas $e$ conselhos práticos para o lar e O livro azul da mulher. Porém, longe de serem realmente veículos para o aprimoramento da mulher, todos procuravam naturalizar o comportamento da leitora a determinado padrão de feminilidade, excluindo o que não interessava à educação eugenista. Daí, o discurso ressaltar sempre a necessidade de transformação da mulher. Dengel, por exemplo, com voz de quem sabe o que diz, afirmou:

Convido-a, portanto, a resolver quanto deseja transformar-se; o que exatamente deseja ser; e, então, não deixe que coisa alguma o impeça. Não importa saber por que deseja melhorar. Qualquer motivo é uma boa justificação. No trabalho que realizei com milhares de mulheres, encontrei todos os motivos possíveis: conservar um marido; às vezes, protegê-lo contra interêsses exteriores; persuadir um rapaz de que aquela era "a moça dos seus sonhos"; ter melhor aparência; melhorar a saúde; saber como se vestir de acordo com o tipo; obter sucesso no mundo dos negócios; tornar-se mais preeminente no seu meio social ou na sua comunidade. (24)

Ou seja, a feminilidade podia ser adquirida, ensinada e aprendida, não dependendo de fatores externos ou hereditários e sim do esforço que a mulher fizesse para estar consoante à imagem discursiva do corpo feminino adequado para atingir a felicidade pensada em três pilares: maternidade, casamento e lar.

Para que esses objetivos fossem alcançados, era essencial a boa aparência, porque uma moça atraente e bonita, de pele sedosa e higiene diária, teria melhores chances de conseguir bom marido e de manter o casamento. Dengel e Quadros não mediram, portanto, esforços para divulgar suas receitas, pois o processo de embelezamento dependia, exclusivamente, da mulher que teria de se 
organizar e adquirir os produtos ou fazê-los em casa para cumprir os programas propostos. Dengel, logo no primeiro capítulo, deixou esse quesito bem claro: "É você que controla seu bem-estar, seus pensamentos, sua aparência e seus atos. É você que faz as coisas que modelarão e lhe darão felicidade" (14-15). Esse discurso de Dengel frisou, inclusive, o pronome "você," chamando a atenção persuasivamente de sua leitora. Para convencê-la que somente ela "pode sonhar os sonhos - e torna-los realidade" (15).

Seguindo os princípios da imprensa feminina, Dengel, no capítulo "Retocando o quadro," de O livro azul da mulher, tratou exatamente dessa questão, impingindo também à mulher, de modo taxativo, a harmonia e felicidade do lar:

Precisarei lembrar à dona de casa que deve estar limpa, fresca e linda quando a família regressar ao lar? Os homens não gostam que as mulheres sejam desalinhadas e que vivam se queixando do trabalho que tiveram durante o dia. Mesmo as crianças notam o aspecto de suas mães, mais do que pensamos, portanto faça com que as recordações de infância de seus filhos, a seu respeito, sejam o que deseja que elas sejam. (393)

Parece cruel reportar à mulher essa responsabilidade de ser bela e feminina. Dengel nesse fragmento persuade sua interlocutora, pela técnica da sugestão, depois de ter estabelecido a relação de confiança com a leitora, por meio de outra técnica de persuasão: o discurso de autoridade. Dengel, primeiramente, apresenta-se como alguém que é especialista no assunto e faz uso da linguagem com marcas linguísticas que não deixem dúvidas em quem a ler. A linguagem que sugestiona, de acordo com James A.C. Brown, não deve discutir. Deve denotar convicção, por meio de um vocabulário simples, mas selecionado. No extrato citado, Dengel parece se dirigir a uma mulher que ainda duvida da importância da higiene nas relações domésticas.

Na página de Tereza Quadros, também vamos encontrar textos que seguem essa mentalidade, adequando-se a fórmulas de comportamento do período. A seção "Conselhos de minha Vizinha"-que será reaproveitada por Clarice Lispector, como a ghost writer da atriz Ilka Soares, para a página "Só para Mulheres" do Diário da Noite - reúne sugestões, digamos, inquestionáveis. A vizinha não é identificada por um nome, uma profissão, uma idade. É anônima. 
Mas sabe de muitos segredos e não se esquiva de revelá-los. Semelhante à técnica persuasiva de Dengel, a colunista Tereza Quadros impele a leitora a agir de forma tão eficiente quanto a vizinha mencionada. Esse saber que é compartilhado na página "Entre Mulheres" vem em doses esquemáticas, como que a compor um guia para a mulher no seu papel dentro de casa. Os conselhos referem-se aos cuidados com o lar, a alimentação da família, o marido. São ainda pequenos truques culinários, de medicina caseira e de beleza. Conselhos que dão a medida de uma mulher prestimosa, econômica e atenciosa. Eis um deles: "Minha vizinha diz que seu marido nunca se queixa do tabaco para o seu cachimbo. Para evitar que o fumo seque com o tempo, ela coloca algumas rodelas de batata ou maçã na caixa ou saco onde ele guarda o tabaco. É um bom modo de conservar a umidade deste" (Comício, 31 de julho de 1952, 18). A leitora de Dengel e Quadros vive em lar burguês. Mas é constantemente ameaçada por uma possível rival. Homens apreciam mulheres que sejam asseadas e que mantenham a casa limpa e confortável, conforme nos ensina O livro azul da mulher. Mas, além de tudo, ela deve ser exemplar para manter a felicidade de seu casamento.

Se os detalhes com a manutenção da casa devem ser observados, as emoções também precisam estar controladas, adverte-nos Quadros. Esbravejar, jamais!, como no conselho a seguir:

Se o terno de linho branco do seu marido voltou do tintureiro com aquela mancha deixada pela caneta-tinteiro, não deixe que ele saia à rua assim, não diga que ele é um descuidado (são coisas que acontecem) e que o tintureiro é um irresponsável. Mande buscar um vidro de hipoclorina, embeba um pedaço de algodão no líquido e vá passando na mancha. Enquanto o diabo pisca um olho, voltará a alvura imaculada do linho. Faça isso, antes que um broto de fora se ofereça ao seu marido para fazê-lo. (Comício, 22 de agosto de $1952,18)$

Como podemos observar, Clarice utilizava temas e discurso condizentes com a proposta dos manuais de comportamento da mulher, decorrente de um pensamento machista, o qual a imprensa brasileira do período compartilhava. Mas Clarice não podia compactuar com isso. Até porque ela, em sua literatura, por exemplo, problematizava a condição feminina. Como, então, produzir um 
jornalismo em que a mulher emancipada não fosse vista como problema social, ao negar o papel de mãe e esposa, conforme o sistema patriarcal vigente nos anos $1950 ?$

\section{Desordem clariciana}

Para a página feminina de Comício, Clarice Lispector idealizou uma seção denominada "Aprendendo a Viver," com o objetivo de ser um espaço conscientizador para a leitora. E dessa maneira, como quem nada quer, começou a instaurar uma desordem na página. Nas receitas do saber viver, Tereza Quadros antecipou discussões que somente ocorreriam de forma mais incisiva na década seguinte. Com o didatismo peculiar da imprensa feminina, a seção cuidou em examinar algumas situações adversas do universo da mulher, emprestando, para isso, a voz de filósofos e especialistas, a fim de auxiliar a leitora em seus conflitos mais íntimos, sempre habituada a seguir os papéis de mãe, esposa e dona de casa.

Com crédito da obra e autoria, Tereza Quadros inseriu em meio aos discursos conservadores de "Entre Mulheres," um excerto de Simone de Beauvoir, extraído da obra O segundo sexo, que só seria publicada no Brasil em 1960. Do capítulo "A mulher independente," do segundo volume, Beauvoir, no fragmento escolhido por Lispector, expôs sua opinião sobre a menstruação ser fator impeditivo para o trabalho da mulher fora de casa. Acompanhemos, pois:

Estou convencida de que a grande maioria dos mal-estares e doenças que atingem as mulheres tem causas psíquicas. É por causa da tensão moral de que eu falei, por causa de todas as tarefas que assumem, das contradições do ambiente no qual se debatem, que as mulheres estão constantemente cansadas, até o limite das forças. Isso não significa que seus males sejam imaginários: eles são reais e devorantes como a situação que exprimem. Mas a situação não depende do corpo, é este que depende dela. Assim, a saúde não prejudicará o trabalho da mulher quando esta tiver na sociedade o lugar de que ela precisa. Pelo contrário, o trabalho a ajudará poderosamente a obter um equilíbrio físico, não the permitindo que se preocupe com este sem cessar. (Comício, 11 de julho de 1952, 20) 
Desse modo, Tereza Quadros propôs debate sobre o trabalho da mulher fora de casa, assunto esse muito caro a Lispector, se lembrarmos que, quando estudante de Direito, em setembro de 1941, ela realizou uma enquete com universitários, sob o título "Deve a mulher trabalhar?," para a revista discente A Época. Com essa fala de Beauvoir, a colunista estava a dizer para sua leitora que os males que afligiam a mulher daquele 1952 não eram infundados. Tinham origem psíquica, devido à sobrecarga de trabalho que o matrimônio impunha sobre seus ombros, anulando a personalidade.

Sobre o trabalho feminino fora de casa, a seção "Aprendendo a Viver" também publicou a opinião de E. Barlow, que acabou por reforçar a de Beauvoir ao concluir que não "trabalhar pareceu-me sempre a mais destruidora das forças" (Comício, 12 de junho de 1952, 18). A fala de Barlow sinalizou pontos para a leitora ponderar o quanto sua rotina destoava da dos homens, sendo-lhe prejudicial e não prazerosa:

Mas um grande "handicap" temos que superar. Depois de passarmos anos e anos a realizar diariamente inúmeras tarefas desconexas, perdemos o hábito da concentração. Deixamo-nos acostumar com o mais devastador de todos os obstáculos-o da interrupção. Desde o primeiro choro do primeiro filho, aceitamos as interrupções como fato normal. Os homens, enquanto trabalham, estão protegidos. Além disso, dispõem de secretárias que se ocupam das coisas que mais os aborrecem e que lhes poupam mil distrações banais. Esse sistema é chamado eficiência. (Comício, 12 de junho de 1952, 18)

Além do excerto mencionado de autoria de Beauvoir, Lispector publicou outros de autores que a escritora francesa incluiu em $O$ segundo sexo, porém a colunista de Comício omitiu a referência. É bem provável que Clarice Lispector tenha ocultado a fonte bibliográfica temendo alguma retaliação. A imprensa brasileira da década de 1950 não tolerava discurso feminista. Além do mais, mesmo tendo vendido vinte e dois mil exemplares, na Europa, na primeira semana de lançamento, em maio de 1949, O segundo sexo motivou a resistência de opositores que se empenharam para que a obra fosse retirada de várias livrarias. 
Nessa ocasião, Clarice estava na Europa e pôde acompanhar de perto essa repercussão. São desse trabalho de Beauvoir, as narrativas que Tereza Quadros se apropriou, como a do psiquiátra Wilhelm Stekel sobre a mulher que se vitimiza e a do poeta Rainer Maria Rilke visitando a casa de Auguste Rodin, para concluir que lar é uma construção feminina, pois para os homens a casa não passa de um abrigo contra o frio ou um teto para dormir.

Mas Tereza Quadros selecionou ainda outras narrativas de temática feminista, como "A irmã de Shakespeare," inspirada no livro Um teto todo seu, de Woolf, que critica o casamento impingido às mulheres como único destino possível, não considerando genialidade e talento femininos. E "Um retrato de mulher," de Bernard Shaw, que enaltece a atriz Sarah Bernhardt, que ultrapassou os limites do de-dentro-de-casa para se realizar nos palcos. É como se a redatora da página feminina de Comício confidenciasse que todas as mulheres deveriam ter a liberdade de se realizarem conforme seus talentos, a exemplo de Sarah Bernhardt, e de não sucumbirem como a talentosa Judith, irmã fictícia de William Shakespeare.

Da biografia da Condessa de Noailles, a coluna publicou pequena crônica (possível tradução de Clarice Lispector) em que a princesa Luísa da Inglaterra seria recepcionada pela então Condessa quando criança. Movida por enorme timidez, a menina acabou pronunciando "your royal honey" (mel real), ao invés de "your Royal Highness" (real grandeza). A reprovação da mãe e o constrangimento que se transformou em sentimento de culpa na menina convidam a leitora carioca a ter olhar mais atento e doce para com as crianças. A narrativa de Noailles nos remete a outra narrativa, a de Lehmann, mais especificamente ao conto "The Gipsy's Baby," que retrata também um período na infância da narradora, quando as crianças de classes privilegiadas eram criadas por babás em um mundo separado dos adultos. Lehmann e Noailles, nesses textos, expõem impressões e lembranças de uma criança, agora adulta, sobre o mundo insensível dos adultos. A contística de Clarice Lispector, devemos lembrar, também se debruçou sobre o universo infantil. Podemos citar "Cem anos de perdão," "Felicidade clandestina" e "Restos de carnaval," que rememoram episódios da infância da escritora em Recife.

Ainda em "Entre Mulheres," a leitora de 1952 tomou contato com a literatura de Mansfield, que igualmente é estudada por Beauvoir na obra citada. Para Comício, Lispector escolheu uma passagem de "At the Bay," em que a 
personagem Linda se queixa da vida, desacreditando do destino da procriação conferido às mulheres. A cena mostra uma mulher fragilizada pelos partos que admite não poder amar os filhos. Estava sem forças.

Outro tipo de desordem clariciana refere-se à temática da higienização do lar. Entre as décadas de 1940 e 1960, o Brasil buscava modernizar-se. Com os avanços da ciência em campos de batalha na Europa, o uso do diclorodifeniltricloroetano, o DDT, considerado o primeiro pesticida moderno utilizado no combate de piolhos transmissores do tifo em soldados, e depois na prevenção da malária e da febre amarela, foi introduzido no ambiente doméstico da classe média brasileira, mostrando-se extremamente eficaz. A publicidade investiu pesado em anúncios para as marcas Detefon, Neocid e Flit, e encontraram no jornalismo feminino e nos manuais de economia doméstica os aliados contumazes em defesa de lares higienizados.
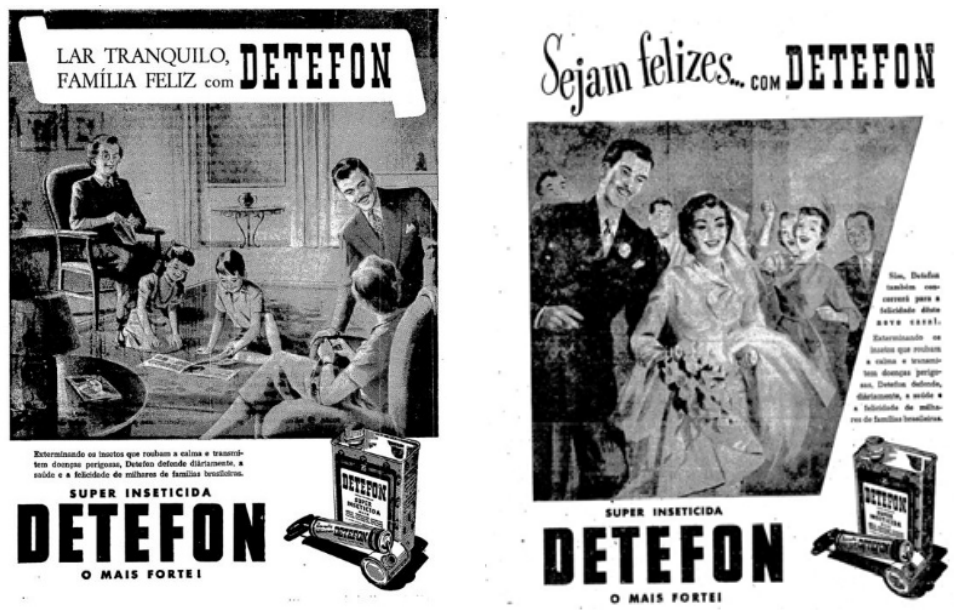

Figura 5: Anúncios do inseticida Detefon, publicados em O Cruzeiro (15 de março de 1952, p. 79 e 26 de janeiro de 1952, p. 111, respectivamente). Arquivo pessoal de Aparecida Maria Nunes.

Nesse cenário, está Tereza Quadros. Motivada provavelmente pelos anúncios em revistas de grande circulação, como O Cruzeiro (figura 5), não foi por acaso que, na edição de 8 de agosto de 1952, a colunista divulgou uma nova receita que teve por título "Meio cômico, mas eficaz." Lembramos aqui que o adjetivo "eficaz" 
era a palavra de ordem na divulgação dos inseticidas, notadamente nos slogans publicitários:

\section{MEIO CÔMICO, MAS EFICAZ ...}

De que modo matar baratas? Deixe, todas as noites, nos lugares preferidos por esses bichinhos nojentos, a seguinte receita: açúcar, farinha e gesso, misturados em partes iguais. Essa iguaria atrai as baratas que a comerão radiantes. Passado algum tempo, insidiosamente o gesso endurecerá dentro das mesmas, o que lhes causará morte certa. Na manhã seguinte, você encontrará dezenas de baratinhas duras, transformadas em estátuas. Há ainda outros processos. Ponha, por exemplo, terebentina nos lugares frequentados pelas baratas: elas fugirão. Mas para onde? $\mathrm{O}$ melhor, como se vê, é mesmo engessá-las em inúmeros monumentozinhos, pois "para onde" pode ser outro aposento da casa, o que não resolve o problema. (Comício, 8 de agosto de 1952)

Sobre a receita de matar baratas em Comício, Tereza Quadros, apesar da estrutura do texto obedecer ao discurso usual de receitas na imprensa feminina, ao dispor para a leitora ingredientes e modo de fazer, além do uso do verbo no imperativo, não temos de fato uma receita, como dissemos, mas uma crônica, com elementos sádicos, da ficção clariciana. Sádicos porque a narradora explana meticulosamente a execução do preparado à base de açúcar, farinha e gesso, que garante o sucesso da higienização, com "esses bichinhos nojentos" transformados em estátuas, uma vez que "o gesso endurecerá dentro das mesmas." A terebentina poderia ser aplicada também, confessou a narradora, para afastar as baratas. Mas o problema não se resolverá, porque elas poderão ir para outro aposento da casa. Então, o melhor mesmo é "engessá-las em inúmeros monumentozinhos."

A receita ficcional que Lispector publicou em Comício terá sua redação refeita e aprimorada em diversas oportunidades pela escritora. Ainda em página feminina, no Diário da Noite, na edição de 16 de agosto de 1960, assinando como Ilka Soares, a crônica recebeu o nome de "Receita de assassinato (de baratas)." No mesmo ano, 1960, mas em outubro, assinando como "Clarice Lispector," na 
revista Casa e Jardim, a narrativa foi divulgada com o nome "A quinta história," em formato mais próximo ao conto. Depois, em abril de 1962, na coluna "Children's Corner" da revista Senhor, assinando C.L., "A quinta história” teve o texto novamente modificado. Na sua coluna para o Jornal do Brasil, em 1969, recebeu o nome "Cinco relatos e um tema." E, em livro, o conto fez parte da edição de 1964 de A legião estrangeira. A receita inicial de matar baratas publicada em Comício inspirou ainda A paixão segundo G.H. (1964), cuja trama se desenrola a partir do momento em que a personagem G.H. encontra uma barata no quarto da empregada. O lar não estava dedetizado, pois.

Tereza Quadros divulgou também, em Comício, crônicas e contos, sem assinatura, dando a entender que fossem de autoria dela mesma, já que estavam em espaço de seu discurso. Mas, na verdade, são de Clarice Lispector, que seriam devidamente reescritos e inseridos em publicações posteriores da escritora. "Um dia cheio" foi selecionado para a obra Onde estivestes de noite (1974), sob o título "Uma tarde plena," em que um sagui quebra a monotonia de uma viagem no bonde, até que um caminhão provoca acidente ao bater no bonde e todos descem correndo. "Hora em que começa o domingo"7 descreve os movimentos de um vento mal-intencionado sobre as páginas de um jornal. O cenário é uma praia um tanto quanto deserta. Mas o vento anuncia uma mudança, como aquelas horas perigosas típicas da ficção clariciana que provocam as epifanias.

\section{Desordem feita}

Quando Clarice chegou ao Rio de Janeiro em março de 1951, já era escritora premiada e muito querida por um grupo de intelectuais brasileiros. Tinha três livros publicados-Perto do coração selvagem, O lustre (1946) e A cidade sitiada - além de contos bem acabados que fariam parte das obras Alguns contos e Laços de família (1960). Estava casada e era mãe de Pedro. Tinha 30 anos de idade e trazia experiências de vida não comuns às mulheres da classe média carioca, para quem produziria, no ano seguinte, a página feminina do tabloide Comício. Das histórias vividas em uma Itália bombardeada pela Segunda Guerra Mundial às recepções diplomáticas do Itamaraty, Lispector reunia conhecimento,

${ }^{6}$ Comício, 11 de julho de 1952, p. 20.

${ }^{7}$ Comício, 22 de agosto de 1952, p. 18. 
requinte e sensibilidade suficientes para se embrenhar por um tipo de jornalismo que ainda não dominava. Mas que não lhe seria difícil realizar.

Na coluna "Entre Mulheres," Lispector identificava muito bem seu públicoalvo. Sabia que o Brasil se modernizava, mas que a sociedade ainda era conservadora. Por isso, tinha de seguir os ditames da imprensa feminina, para atrair a leitora mediante a identificação com temas e problemas próximos ao cotidiano no qual vivia. Mas essa Clarice amadurecida continuava ousada, como a principiante repórter que foi. E preferiu investir em textos voltados para um feminismo convicto, sem ser ativista. As páginas femininas de Comício estavam ancoradas nos manuais de comportamento e beleza, idealizados para "orientar" a mulher em seu destino de esposa, mãe e dona de casa. Tereza Quadros deveria dialogar com a linha editorial dessas produções, que delineavam um perfil de mulher moderna, mas que, ao mesmo tempo, deveria cuidar do lar e de sua família. Finge se adaptar a essa concepção de mulher pretendida pela sociedade pós-guerra. Insere em suas páginas alguns conselhos baseados nas ideias de Veronica Dengel, estruturadas no best seller O livro azul da mulher e de outros tantos manuais de beleza. Mas, irrompe a coluna com textos capazes de desarticular a comodidade de um lar feliz e harmônico. Mais que ensinar como conservar o marido e protegê-lo de interesses alheios (outras mulheres), de saber como se vestir conforme o tipo físico e estar na moda, Tereza Quadros se preocupou em oferecer a sua leitora alguns pontos de reflexão da condição feminina considerados progressistas e assustadores para 1952.

Com esse projeto editorial, Lispector introduz excertos de Beauvoir, Mansfield, Woolf e Condessa de Noialles, entre outras, para remover a leitora de sua zona de conforto, com discussões, por exemplo, sobre a necessidade de a mulher ter um trabalho fora do lar e sobre uma mãe não amar o filho. Revolucionária a seu tempo, "Entre Mulheres" nos ajuda a entender Lispector, sua literatura e seu jornalismo. E no jornalismo feminino que realizou, na construção do perfil de mulher que legou à leitora de Comício, nos expôs a Lispector que retornou ao Brasil. Ficam evidentes na página feminina de Tereza Quadros as influências de leituras feitas e as afinidades com outras escritoras, ao privilegiarem o olhar para coisas miúdas e o despertar da personalidade feminina, sufocada pelas banalidades do cotidiano provinciano. 


\section{Obras citadas}

Abreu, Alzira Alves de, editor. A imprensa em transição: o jornalismo brasileiro nos anos 50. Fundação Getúlio Vargas, 1996.

Beauvoir, Simone de. O segundo sexo: fatos e mitos. Nova Fronteira, 1980.

—. O segundo sexo: a experiência vivida. Difusão Europeia do Livro, 1967.

Brown, James A.C. Ténicas de persuasão: da propaganda à lavagem cerebral. Zahar, 1965.

Buitoni, Dulcília Helena Schroeder. Mulher de papel: A representação da mulher pela imprensa feminina brasileira. Loyola, 1981.

Dengel, Veronica. Beleza e personalidade por Veronica Dengel: O livro azul da mulher. O Cruzeiro, 1956.

Lehmann, Rosamond. The Gipsy’s Baby. Virago, 1998.

Lispector, Clarice. A cidade sitiada. A Noite, 1949.

- A descoberta do mundo. Nova Fronteira, 1984.

-. A legião estrangeira. Editora do Autor, 1964.

-. A paixão segundo G.H. Editora do Autor, 1964.

—. Alguns contos. Ministério da Educação e Saúde, 1952.

—. Laços de família. Francisco Alves, 1960.

—. Minhas queridas. Editado por Teresa Montero, Rocco, 2007.

—. O lustre. Agir, 1946.

- Perto do coração selvagem. A Noite, 1943.

Mello e Souza, Gilda de. "Entrevista." Revista Língua e Literatura, vol. 10-13, 1981, pp. 9-34.

Nunes, Aparecida Maria. Clarice Lispector jornalista: páginas femininas \& outras páginas. Senac, 2006.

- "Clarice Lispector na imprensa brasileira." Mulheres e literatura: (trans)formando identidades, editado por Rita Terezinha Schmidt, Palloti, 1997.

—, editora. Clarice na cabeceira: jornalismo. Rocco, 2012.

—, editora. Correio feminino. Rocco, 2006.

Sullerot, Evelyne. La presse féminine. Armand Colin, 1963.

Woolf, Virginia. Un teto todo seu, traduzido por Bia Nunes de Souza, Tordesilhas, 2014. 